\title{
PELATIHAN PENCEGAHAN PENULARAN WABAH COVID-19 BAGI STAF KARYAWAN HOTEL NUTANA KOTA MATARAM
}

\section{Training for Prevention of Covid-19 Distribution for Nutana Hotel Employee Staff}

\author{
Eustachius Hagni Wardoyo ${ }^{1,2}$, Wahyu Sulistya Affarah ${ }^{1,2}$, Adnanto Wiweko ${ }^{1,2}$, Ahmad \\ Taufik Sakti $^{1,2}$, Didit Yudhanto ${ }^{1,2}$, Monalisa Nasrul ${ }^{1,2}$ dan Prima Belia Fathana ${ }^{1,2}$ \\ ${ }^{1}$ Program Studi Pendidikan Dokter Fakultas Kedokteran Universitas Mataram, ${ }^{2}$ Rumah Sakit \\ Pendidikan Universitas Mataram
}

Jalan Pendidikan Nomor 37 Kota Mataram Provinsi NTB

*Alamat korespondensi : wardoyo.eh@unram.ac.id

(Tanggal Submission: 23 July 2020, Tanggal Accepted: 30 Agustus 2020)

\begin{abstract}
ABSTRAK
Bidang perhotelan merupakan salah satu usaha perekonomian yang paling terdampak dari pandemi COVID-19, ketiadaan tamu, penurunan kunjungan restoran, penurunan jumlah event dan meeting. Salah satu bentuk adaptasi yang dapat dilakukan oleh para pelaku di bidang ini adalah dengan membuka/mengadakan paket isolasi mandiri bagi tamu yang terindikasi/terpapar dengan wabah covid-19. Kegiatan pengabdian kepada masyarakat ini bertujuan untuk meningkatkan pengetahuan tentang pencegahan dan pengendalian wabah covid 19 bagi para staf dan karyawan hotel Nutana Kota Mataram. Pengetahuan tersebut diharapkan dapat bermanfaat dalam rangka pelayanan paket isolasi mandiri yang sesuai dengan protokolo kesehatan yang berlaku. Kegiatan pengabdiam masyarakat ini di adakan di Hotel Nutana, Jl. Airlangga Gomong Mataram yang memiliki 42 kamar dan termasuk hotel menengah. Pelatihan dihadiri oleh berbagai unsur perhotelan, petugas front office, housekeeping, sekuriti, laundry dan restoran sebanyak 16 orang. Pelatihan ini meliputi proses penerimaan tamu, skema paket isolasi mandiri, alur pencegahan infeksi bagi tamu dan karyawan, jenis-jenis APD, prosedur kerja house keeping, laundry dan restoran. Pada akhir pelatihan, pemahaman karyawan terkait praktek isolasi mandiri meningkat dan karyawan siap untuk mengimplementasikan paket isolasi mandiri yang dimaksud.
\end{abstract}

Kata kunci : pencegahan, penuluaran, virus corona, covid19

\section{PENDAHULUAN}

Corona Virus Diseases (COVID-19) yang disebabkan oleh virus SARS-COV-2 telah dinyatakan sebagai pandemi oleh WHO sejak 11 Maret 2020. Saat ini telah menginfeksi 6.193.548 dan menyebabkan kematian 372.479 orang secara global. Jumlah Covid-19 di Indonesia saat ini sudah mencapai 26.940 dengan kematian 1.641 orang dengan kesembuhan 7.637 orang. (John Hopskin University GIS and Data, 2020; Kemenkes, 2020).

Pandemi COVID-19 membawa konsekuensi diberbagai bidang dan mempengaruhi seluruh dunia. Bidang ekonomi, kesehatan, pendidikan, sosial politik, pertahanan dan keamanan, budaya dan agama tak luput dari kerusakan kolateral pandemi ini (The Jakarta Post, 2020; The Hospitalitynet, 2020; World Economic 
Forum, 2020). Pulau Lombok sebagai pulau pariwisata tidak terkecuali mengalami kelumpuhan ekonomi utama yakni pariwisata.

Jumlah karyawan yang dirumahkan dari bidang industri pariwisata semakin meningkat, baik industri pariwisata utama (perhotelan, restoran, transportasi, wahana wisata, dive center, hiking center, tourist guide) maupun industri pariwisata pendukung (peternakan hewan, pelayanan kesehatan, pasar tradisional, toko oleholeh dan cinderamata) (BBC, 2020). Sebanyak 73 orang karyawan industri wisata labuan Bajo di PHK dan 1.506 dirumahkan (Kompas, 2020). Berbagai upaya dilakukan oleh industri-industri ini, namun masih sebatas dalam bertahan hidup.

UNWTO, organisasi kepariwisataan dunia mengeluarkan pernyataan bahwa kegiatan kepariwisataan yang memungkinkan dijalankan adalah kegiatan yang minim risiko penularan. Menempatkan keselamatan orang diatas kepentingan bisnis diterapkan pada setiap lini kegiatan pariwisata (UNWTO, 2020).

Pada kegiatan pengabdian ini, sebelumnya telah diinisiasi dengan kerjasama antara RS Universitas Mataram dan Hotel Nutana dalam memulai paket program isolasi diri di hotel selama 14 hari. FK Unram/RS Unram mengadakan pengabdian kepada masyarakat ini. Ketentuan kerjasama ini dengan masuk dan keluar hotel mendapatkan paket pemeriksaan rapid test dengan menghadirkan petugas RS ke hotel. Sebelum dilakukan pemasaran paket tersebut, pegawai dan manajemen hotel perlu dilatih dalam pelayanan perhotelan yang memperhatikan prosedur pencegahan penularan COVID-19 (WHO, 2020). Fakultas Kedokteran/RS Universitas Mataram menyelenggarakan pengabdian masyarakat yang berjudul "Pelatihan Pencegahan Penularan COVID-19 di Hotel Nutana Mataram dalam rangka pelayanan Isolasi Mandiri bagi Tamu".

\section{METODE KEGIATAN}

Dalam pelatihan ini perlu diupayakan pelatihan yang menyenangkan, mudah diterima dan benar-benar diimplementasikan oleh seluruh karyawan hotel dengan baik. Pelatihan menggunakan bahasa sehari-hari yang mudah dimengerti oleh orang awam kesehatan, diselingi diskusi disela-sela penyampaian materi. Ruang pelatihan didesain berjarak $>1$ meter tiap kursinya, seluruh pelatih dan peserta cuci tangan sebelum dan sesudah memasuki aula pertemuan dan mengenakan masker. Pelatih dipersiapkan materimateri pencegahan COVID-19 meliputi: pengetahuan umum pencegahan COVID-19, praktek pencegahan yang sesuai dengan area kerja hotel.

Materi pengetahuan umum: apa itu Virus Corona dan bagaimana dia bisa menular antar manusia, apa saja alat pelindung diri yang diperlukan, bagaimana cara pemakaian yang benar. Bagaimana cuci tangan yang baik menggunakan air mengalir dan sabun cair, langkah-langkah dan lama cuci tangan.

Materi pencegahan spesifik sesuai area pelayanan: 1. front office: manfaat check in online dan cashless payment, barier plastik dimeja front office, ketersediaan wastafel/hand sanitizer, salam namaste, program tegur sapa tamu melalui telepon 2-3 hari sekali. 2. Sekuriti: pengaturan parkir, pemeriksaan suhu tubuh, mengarahkan cuci tangan dan mengoreksi pemakaian masker dan mengamankan kamar hotel dari interaksi tamu-tamu, karyawan-karyawan, tamu-karyawan.

3. House keeping: pembersihan kamar tidak dilakukan oleh petugas, pemberian seprai bersih dan alat mandi setiap 3 atau 6 hari sekali, penyediaan disposal bag yang mencukupi untuk 3 atau 6 hari sekali, pengemasan pakaian yang hendak dilaundri. 4. Restoran: meal service diberikan ke kamar, penggunaan alat makan menggunakan alat makan sekali pakai.

Pelatihan dilakukan tanggal 21 April 2020

dan evaluasi dilakukan setelah implementasi 
minggu ke-empat (30 Mei 2020). Untuk memberikan solusi terhadap permasalahan yang dimiliki oleh mitra, pemberian materi dilakukan melalui 4 tahapan:

1. Tahap perkenalan

2. Tahap pemberian materi

3. Tahap praktek pencegahan

4. Tahap evaluasi

\section{Tahap perkenalan}

Tahapan ini masing-masing pelatih dan karyawan saling memperkenalkan diri. Dilanjutkan dengan perkenalan apa itu isolasi mandiri, mengapa isolasi dilakukan selama 14 hari. Do's dan dont's bagi tamu selama isolasi diri, do's dan dont's bagi karyawan hotel.

\section{Tahap pemberian materi}

Tahap pemberian materi terkait pengetahuan umum COVID-19 dan pencegahan infeksi spesifik di area pelayanan.

\section{Tahap praktek pencegahan}

Tahap ini dilakukan kunjungan ke kamar, modifikasi alur kedatangan tamu, perlakuan terhadap barang bawaan tamu, pembersihan permukaan menggunakan desinfektan dan momen-momen cuci tangan bagi tamu dan karyawan.

\section{Tahap evaluasi}

Evaluasi dilakukan menggunakan kuisioner kepuasan bagi karyawan dan tamu. Kepuasan karyawan dinilai dari 4 aspek: 1. Kepuasan pencegahan infeksi yang dilakukan, 2. Kepuasan terhadap ritme kerja baru, 3. Penghasilan, 4. Kepuasan terhadap suplai alat pelindung diri dari hotel. Kuisioner kepuasan tamu meliputi 4 aspek: 1 . Keluarga terdekat aman dari risiko penularan, 2. Kejelasan alur pencegahan infeksi, 3. Koneksi internet, 4. Biaya yang dikeluarkan.

\section{HASIL DAN PEMBAHASAN}

Setelah dilakukan penyampaian materi, diskusi berlangsung seru. Terutama pertanyaanpertanyaan yang berhubungan apa saja yang harus dilakukan karyawan sepulang kerja. Pertanyaan terkait semudah apa virus berpindah dari orang ke orang lainnya dan teknis-teknis terkait alur kedatangan dan kepulangan tamu.

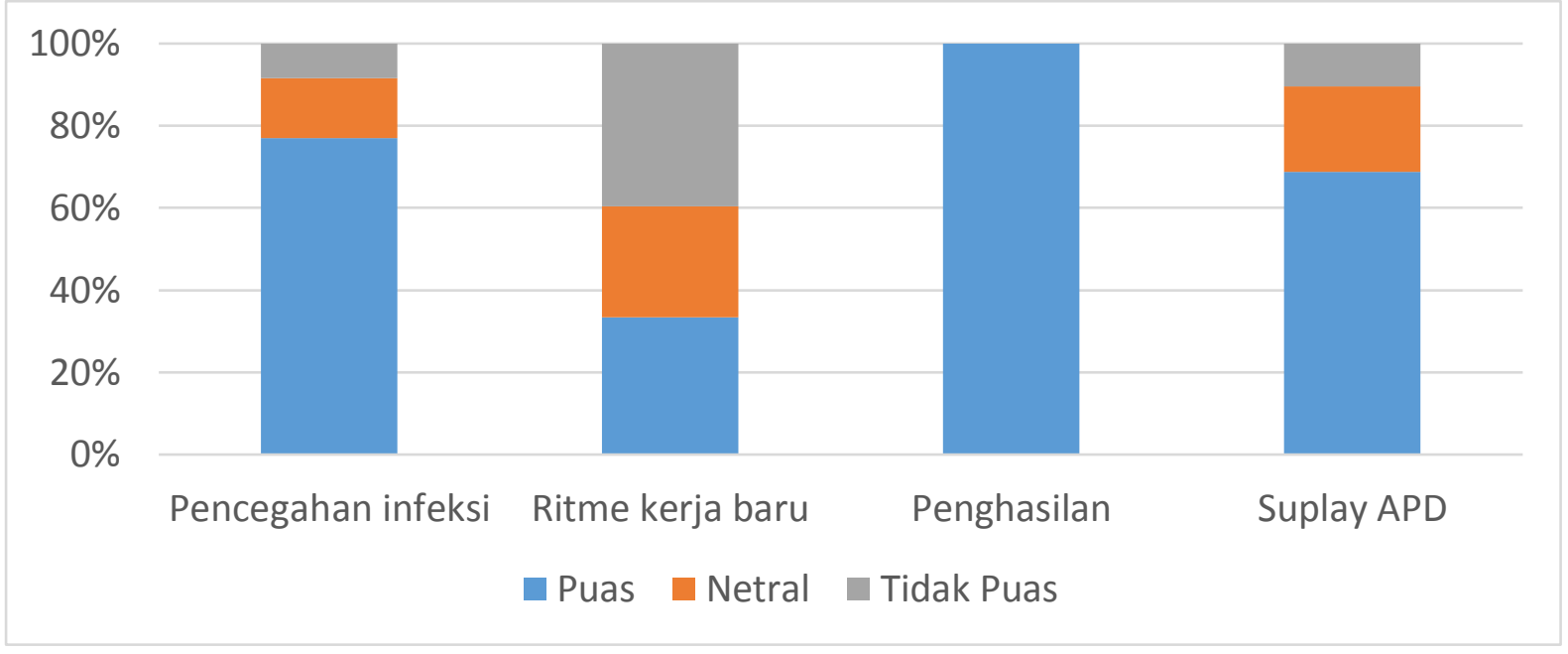

Gambar 1. Hasil penilaian kepuasan karyawan $(n=48)$ pada minggu keempat

Dari gambar 1 didapatkan kepuasan karyawan didapatkan tertinggi pada aspek penghasilan (100\%), disusul aspek pencegahan infeksi $(77,08 \%)$, suplay alat pelindung diri $(68,75 \%)$ dan ritme kerja (33,33\%). Dapat dianalisa bahwa penghasilan menjadi pendorong utama kepuasan karyawan ditambah dengan pembekalan pengetahuan pencegahan infeksi yang baik dan 
tanggung jawab manajemen dalam menyediakan alat pelindung diri yang kontinyu. Namun memang pada minggu keempat, karyawan belum terbiasa dengan adaptasi ritme kerja baru yang berbeda dengan kondisi normal.

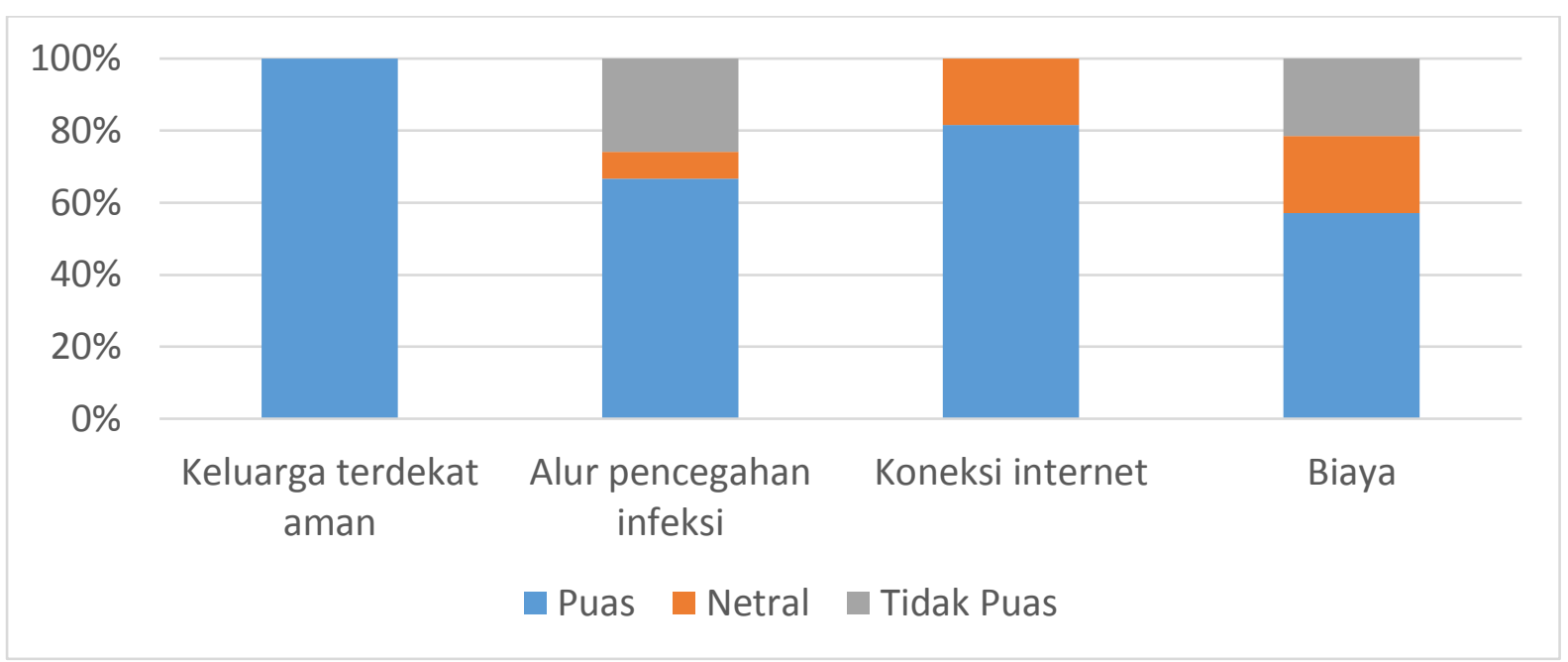

Gambar 2. Hasil penilaian kepuasan tamu $(n=27)$ pada minggu keempat

Pada gambar diatas, dapat dilihat bahwa kepuasan tertinggi tamu pada keluarga terdekat terlindungi (100\%), disusul dengan koneksi internet $(81,48 \%)$, alur pencegahan infeksi yang mudah dipahami dan ditaati $(66,67 \%)$ dan biaya (59,25\%). Dari hasil tersebut tampak pada kepuasan diletakkan pada, jika mereka melakukan isolasi mandiri, ini merupakan kebijaksanaan pribadi dalam melindungi keluarga terdekat. Selanjutnya adalah koneksi internet menjadi sandaran utama para tamu untuk mereka tetap terhubung dengan dunia luar, komunikasi yang lancar dengan keluarga dan kerabat. Pemahaman alur pencegahan infeksi sebagian besar tamu merasa wajar dan mudah untuk ditaati, rerata responden mulai merasa bosan pada hari keenam. Untuk mengatasinya biasanya dihabiskan dengan menonton televisi, surfing internet dan berkomunikasi dengan keluarga. Untuk pembiayaan isolasi mandiri, karena didorong untuk mengamankan keluarga tercinta dirumah, lebih dari separuh responden merasa biaya yang dikeluarkan adalah wajar.

Evaluasi dilakukan setelah pelayanan Isolasi Mandiri telah berlangsung selama 4 minggu, dilakukan terhadap 4 penilaian: 1 . Tingkat hunian (Occupancy rate), 2. Kepuasan karyawan, 3. Kepuasan tamu, dan 4. Hasil pemeriksaan rapid test karyawan.

Tabel 1. Peniaian pre dan saat implementasi paket isolasi mandiri

\begin{tabular}{lllll}
\hline & $\begin{array}{l}\text { Tingkat hunian } \\
\text { (jumlah kamar: } \\
\text { 42) }\end{array}$ & $\begin{array}{l}\text { Kepuasan } \\
\text { karyawan } \\
(\mathrm{n}=48)\end{array}$ & $\begin{array}{l}\text { Kepuasan } \\
\text { Tamu }(\mathrm{n}=27)\end{array}$ & $\begin{array}{l}\text { Rapid test } \\
\text { karyawan } \\
(\mathrm{n}=48)\end{array}$ \\
\hline Pre-paket isolasi & Tidak dinilai & Tidak dinilai & Tidak dinilai & Reaktif: 0 \\
\hline $\begin{array}{l}\text { Implementasi paket } \\
\text { isolasi (minggu ke-4) }\end{array}$ & $100 \%$ & $69,79 \%$ & $76,85 \%$ & $\begin{array}{l}\text { Reaktif: } 1 \\
(2 \%)\end{array}$ \\
\hline
\end{tabular}

Berdasarkan tabel 1. Menggambarkan bahwa terjadi kenaikan tingkat hunian dari 0 
karena tutup sementara menjadi penuh (100\%), kepuasan karyawan dan tamu dinilai menggunakan kuisioner singkat yang keduanya menunjukkan kepuasan diatas $50 \%$ bagi karyawan dan tamu. Tidak semua tamu bersedia mengisi kuisioner yang diajukan (27/42). Hasil uji cepat menunjukkan 1 reaktif tanpa disertai adanya keluhan/gejala. Manajemen mengistirahatkan 1 karyawan sesuai dengan prosedur isolasi mandiri.

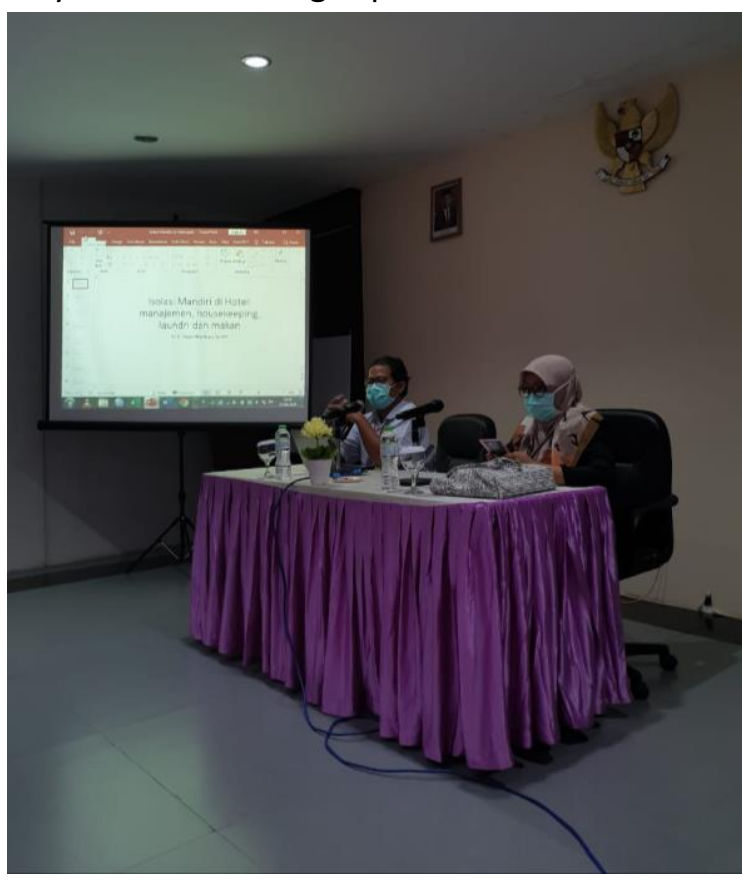

Gambar 3. Pembukaan pelatihan

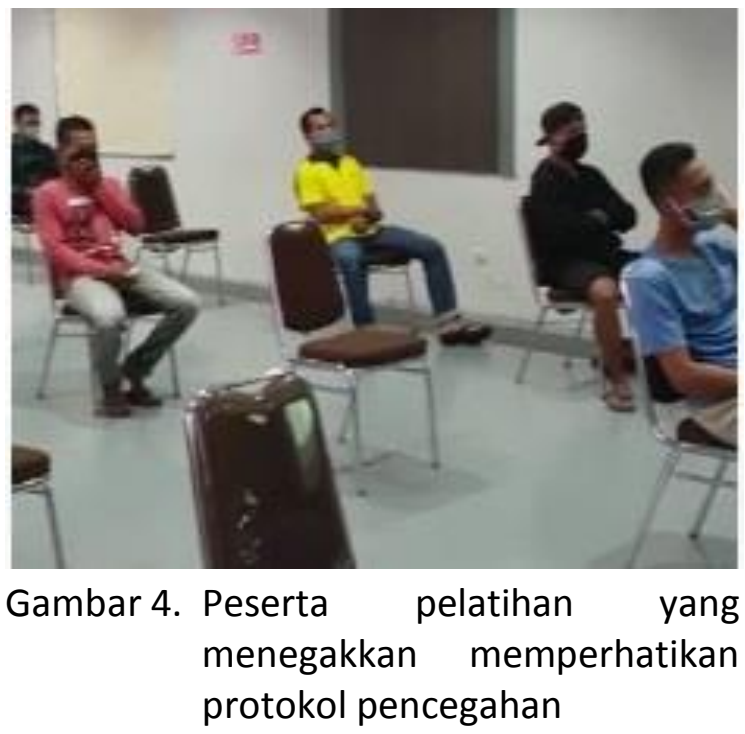

protokol pencegahan

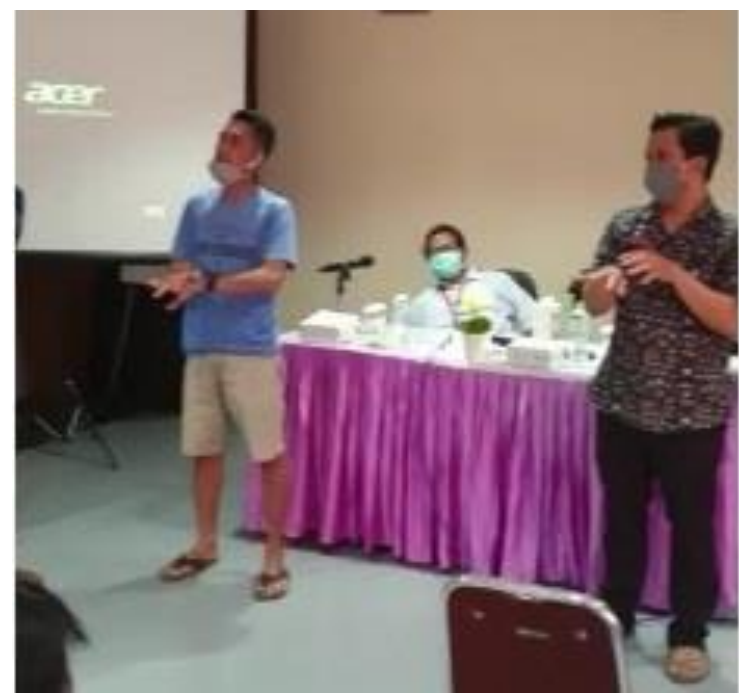

Gambar 5. Peserta langsung mempraktekkan cuci tangan yang baik dan benar

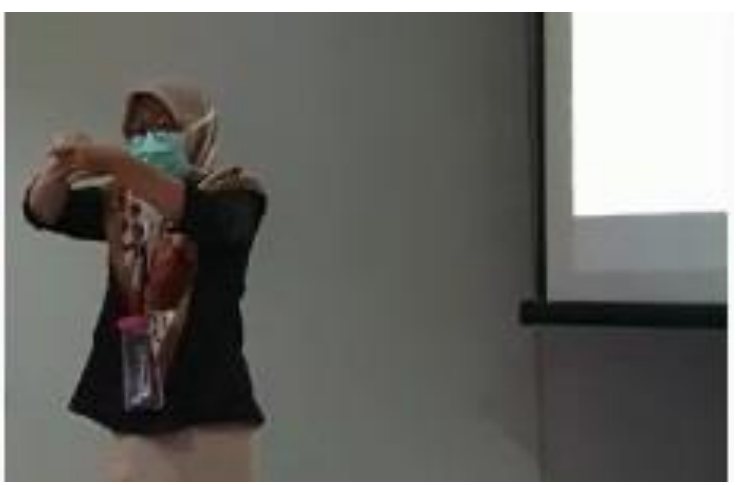

Gambar 6. Pelatih mendemonstrasikan teknik cuci tangan sesuai WHO (2009)

\section{KESIMPULAN DAN SARAN}

1. Paket isolasi mandiri berhasil dilaksanakan dengan memperhatikan protokol pencegahan kesehatan

2. Kepuasan karyawan terhadap pelaksanaan paket isolasi diatas $50 \%$, terutama pada aspek penghasilan

3. Kepuasan tamu sangat baik (>75\%) dengan aspek tertinggi pada rasa aman dari menularkan ke keluarga terdekat.

4. Evaluasi keberhasilan pencegahan infeksi ini perlu dilakukan secara 
periodik, tidak hanya 4 minggu

implementasi paket isolasi.

\section{DAFTAR PUSTAKA}

BBC. Virus corona: Sekitar 50 juta orang akan kehilangan pekerjaan di sektor pariwisata akibat pandemi. 14 Maret 2020.

https://www.bbc.com/indonesia/in donesia-51764525

https://www.weforum.org/agenda/2020/0

3/the-economic-geopolitical-andhealth-consequences-of-covid-19/

John Hopskin University GIS and Data. 2020. Daily Updated on Global COVID data.

https://gisanddata.maps.arcgis.com /apps/opsdashboard/index.html\#/b da7594740fd40299423467b48e9ec f6 akses tanggal 1 Juni 2020

Kemenkes, 2020. Data COVID di Indonesia www.covid19.go.id diakses tanggal 1 Juni 2020

Kompas 22 April 2020. 73 Pegawai Industri Pariwisata Labuan Bajo Kena PHK, 1.506 Orang Dirumahkan. https://travel.kompas.com/read/20 20/04/22/220300127/73-pegawai- industri-pariwisata-labuan-bajokena-phk-1.506-orang-dirumahkan The Hospitalitynet. Coronavirus: Impact on the Hospitality Industry. https://www.hospitalitynet.org/hot topic/coronavirus

The Jakarta Post, March 30, 2020. COVID19 impacts across Indonesia's business sectors: A recap. Available at

https://www.thejakartapost.com/n ews/2020/03/30/covid-19-impactsacross-indonesias-business-sectorsa-recap.html

UNWTO. COVID-19: Putting People First. Akses tanggal 29 Agustus 2020. https://www.unwto.org/tourismcovid-19

WHO. 2020. Getting your workplace ready for COVID-19.

https://www.who.int/docs/defaultsource/coronaviruse/gettingworkplace-ready-for-covid19.pdf?ua $=1$

World Economic Forum. The economic, geopolitical and health consequences of COVID-19 